\title{
Gut Bacteria and Hydrogen Sulfide: The New Old Players in Circulatory System Homeostasis
}

\author{
Lenka Tomasova ${ }^{1,2}$, Piotr Konopelski ${ }^{1}$ and Marcin Ufnal ${ }^{1, *}$ \\ 1 Department of Experimental Physiology and Pathophysiology, Laboratory of Centre for Preclinical Research, \\ Medical University of Warsaw, Warsaw 02 091, Poland; lennytomasova@gmail.com (L.T.); \\ piotr.konopelski@wp.pl (P.K.) \\ 2 Institute of Clinical and Translational Research, Biomedical Research Center, Slovak Academy of Sciences, \\ Bratislava 845 05, Slovakia \\ * Correspondence: mufnal@wum.edu.pl; Tel./Fax: +48-22-116-6195
}

Academic Editors: Noriyuki Nagahara and Maria Wrobel Received: 5 October 2016; Accepted: 14 November 2016; Published: 17 November 2016

\begin{abstract}
Accumulating evidence suggests that gut bacteria play a role in homeostasis of the circulatory system in mammals. First, gut bacteria may affect the nervous control of the circulatory system via the sensory fibres of the enteric nervous system. Second, gut bacteria-derived metabolites may cross the gut-blood barrier and target blood vessels, the heart and other organs involved in the regulation of the circulatory system. A number of studies have shown that hydrogen sulfide $\left(\mathrm{H}_{2} \mathrm{~S}\right)$ is an important biological mediator in the circulatory system. Thus far, research has focused on the effects of $\mathrm{H}_{2} \mathrm{~S}$ enzymatically produced by cardiovascular tissues. However, some recent evidence indicates that $\mathrm{H}_{2} \mathrm{~S}$ released in the colon may also contribute to the control of arterial blood pressure. Incidentally, sulfate-reducing bacteria are ubiquitous in mammalian colon, and $\mathrm{H}_{2} \mathrm{~S}$ is just one among a number of molecules produced by the gut flora. Other gut bacteria-derived compounds that may affect the circulatory system include methane, nitric oxide, carbon monoxide, trimethylamine or indole. In this paper, we review studies that imply a role of gut microbiota and their metabolites, such as $\mathrm{H}_{2} \mathrm{~S}$, in circulatory system homeostasis.
\end{abstract}

Keywords: microbiota; gut bacteria; hydrogen sulfide; sulfur; TMAO; indole; cardiovascular diseases; hypertension

\section{Introduction}

Increasing evidence suggests that mammalian homeostasis strongly depends on a mutualistic relationship with gut bacteria, and fecal transplantation has recently become a therapeutic option for some intestinal, life-threatening diseases [1]. Interestingly, it has been found that metabolic and cardiovascular diseases, including hypertension, are associated with gut microbiota dysbiosis [2-8], and some studies suggest that fecal transplantation may also be a therapeutic target in cardiovascular and metabolic diseases $[4,9,10]$.

A number of studies have shown that hydrogen sulfide $\left(\mathrm{H}_{2} \mathrm{~S}\right)$ and / or the products of its oxidation regulate functions of biological systems, including the circulatory system. Thus far, research has focused on the effects of $\mathrm{H}_{2} \mathrm{~S}$ enzymatically produced by mammalian tissues. However, some recent evidence indicates that $\mathrm{H}_{2} \mathrm{~S}$ released by bacteria in the colon may also contribute to the control of arterial blood pressure [11,12]. Incidentally, sulfate-reducing bacteria are ubiquitous in mammalian colon, and $\mathrm{H}_{2} \mathrm{~S}$ is just one among a number of molecules produced by the gut flora. In this paper, we review studies that imply a role of gut microbiota and gut-bacteria-derived molecules, such as $\mathrm{H}_{2} \mathrm{~S}$, in circulatory system homeostasis. 


\section{Sulfur Bacteria and Life's Origins}

The evolution of Earth is defined by four eons. The Earth was formed in the Hadean eon $\sim 4.6$ billion years ago. Life on Earth evolved in the Archean eon ( $\sim 3.8$ billion years ago) in Ferruginous Ocean $[13,14]$. After the great oxidation event in the Proterozoic eon $(\sim 2.3$ billion years ago $)$ the concentration of oxygen in the atmosphere increased several times, reaching $\sim 2 \%$. Oceans remained anoxic until the beginning of the Phanerozoic eon $~ 800$ million years ago, when the first modern plants appeared. Theories of life's origins are trying to answer the question: What was the energy source for driving metabolism in the first organisms? Several lines of evidence suggest that $\mathrm{H}_{2} \mathrm{~S}$ was a likely candidate for the first anoxic photosynthetic pathways [15-17]. The existence of sulfidogenic organisms in the Archeon is supported by the observation of microfossils-pyrite-associated cells, which are $\sim 3.4$ billion years old [18]. First, bacteria were likely sulfur/sulfite disproportionators and sulfite reducers, as these sulfur forms were abundant in the ancient hydrothermal vents. After the great oxidation event in the Proterozoic, sulfate levels in oceans increased, resulting in the domination of sulfate-reduction metabolism [19]. With the raise in the ocean's oxygen level in the Phanerozoic, the sulfate-reducing bacteria (SRB) were forced to retreat to suboxic and anoxic zones of marine sediments. However, SRB found a suitable anaerobic environment in the gut of mammals.

The modern history of $\mathrm{H}_{2} \mathrm{~S}$ is mostly associated with its toxic effects. For the first time, the toxic effects of $\mathrm{H}_{2} \mathrm{~S}$ were described in 1713 by Italian physician Bernardino Ramazzini, the father of occupational medicine. Later, $\mathrm{H}_{2} \mathrm{~S}$ was used as a chemical weapon in 1916 during World War I. It was only two decades ago, when Abe and Kimura proposed the role of $\mathrm{H}_{2} \mathrm{~S}$ as an important biological mediator [20]. Since then, studies have shown that $\mathrm{H}_{2} \mathrm{~S}$ is involved in biological signaling in numerous biological systems. Among other biological effects, $\mathrm{H}_{2} \mathrm{~S}$ have been reported to exert a hypotensive, cardioprotective and cytoprotective impact [21-26].

The research on the regulatory role of $\mathrm{H}_{2} \mathrm{~S}$ in the circulatory system thus far has focused mainly on the effects of $\mathrm{H}_{2} \mathrm{~S}$ produced by enzymes in the heart, kidneys, vasculature or the brain, while the hemodynamic effect of the gut-bacteria-derived $\mathrm{H}_{2} \mathrm{~S}$ has not been evaluated. The biological action of $\mathrm{H}_{2} \mathrm{~S}$ produced by the gut microbiota was examined only locally in the gastrointestinal tract [27].

\section{Gut Bacteria in Mammals: Commensal or Mutualistic Relationship}

The mammalian gut is colonized early after birth by bacteria and fungi. The composition of the gut microflora is age, diet and geography dependent [28,29]. Furthermore, the mode of delivery and postnatal feeding shape the microbiota composition, with enriched microflora in vaginal-birth and breastfed babies compared to cesarean-birth and formula-fed babies [30,31]. It is estimated that approximately $10^{14}$ microbes colonize the healthy mammalian gut. Several bacterial phyla are present in the gut, including Firmicutes, Bacteroidetes, Actinobacteria, Proteobacteria, Verrucomicrobia and Fusobacteria [32].

Gut microbiota plays an important role in the gut motility regulation, dietary fiber and polyphenol digestion, bile acid and steroid transformation, and xenobiotic degradation. Furthermore, it produces a number of various metabolites, such as vitamin $\mathrm{K}$, a key factor in blood clotting. Short-chain fatty acids (acetic, propionic and butyric acid) are formed from undigested carbohydrates complexes as a result of bacterial fermentation carried out by Lactobacillus and Bifidobacterium. The fatty acids serve as an energy source for colonic intestinal cells and suppress the growth of pathogens by reducing the gut $\mathrm{pH}$ [7]. In addition, toxic metabolites (bacteriocins, ammonia, indoles, and phenols) are produced by the gut microbiota inhibiting the colonization of intestines by pathogens. Sulfate and $\mathrm{CO}_{2}$ reduction in the gut results in the formation of $\mathrm{H}_{2} \mathrm{~S}$ or methane, respectively. Physiological and/or pathological effects of those gut-derived gaseous metabolites remain unclear. However, it was proposed that altered metabolism of gut-derived metabolites may play a role in the pathogenesis of several diseases [33-36]. 


\subsection{Gut Bacteria and the Circulatory System}

Gut bacteria may affect the regulation of the circulatory system via at least two pathways. First, gut bacteria and/or their metabolites may stimulate the enteric nervous system. The latter communicates with the brain via afferent sensory fibers. Such a signal may affect the activity of the brain centers involved in the circulatory system control [37]. This pattern of gut-brain axis communication has been previously described for cytokines [38].

Second, gut bacteria and their metabolites may enter the circulation and affect the function of organs and tissues that play a major role in circulatory system homeostasis. The access of gut-derived molecules to the bloodstream is guarded by the gut-blood barrier (GBB), a complex multilayer system which prevents the free passage of compounds between the gut lumen and circulation [39].

\subsection{The Gut-Blood Barrier}

The GBB enables the absorption of nutrients from intestines, and the same time restricts the passage of pathogens and toxins to the blood [39]. The proper functioning of the GBB may be altered in various diseases [40]. An easier access of gut-derived molecules to the circulation may affect the course of underlying disease and may have a deleterious effect on the entire organism. The integrity and proper functioning of the GBB are preserved by physical and immunological components. The physical barrier is represented by a single layer of epithelial cells which regulate paracellular diffusion and control water and ion absorption. This layer is formed mostly by enterocytes, goblet cells (producing an amorphous polymer-like mucus covering the epithelial cell surface), and immune active Paneth cells. The inner layer of the mucus prevents the adhesion of pathogens to epithelial cells, while the outer layer forms an environment for the commensal bacteria. Interestingly, it has been found that commensal microbiota enhance the integrity of the GBB [2,7]. An immune defense against pathogens, but not against commensal bacteria, is controlled by the system of gut-associated lymphoid tissue.

Recent studies have pointed to a link between gut microbiota dysbiosis, altered levels of gut-derived metabolites, the GBB dysfunction (GBB leaking), and pathophysiology of various diseases [3-5,7,8,10,35,41-44]. For example, several papers examined the function of the GBB in heart failure $(\mathrm{HF})$, reporting alternations in the GBB permeability and morphology, a reduction in gut blood flow, an increased colonization with specific anaerobes, and higher endotoxin levels in HF patients [45-47]. The intestinal blood flow reduction and collagen accumulation were found in patients with advanced HF complicated by cachexia [45,48]. Higher blood endotoxin and cytokine levels were found in edematous HF patients, suggesting that edematous gut wall and epithelial dysfunction resulted in the passage of inflammatory factors into the circulation $[46,49]$.

\subsection{Gut Bacteria in Cardiovascular and Metabolic Diseases}

Recently, the restoration of altered gut microbiota by diet, probiotics, prebiotics or by fecal transplantation has been proposed as a potential therapeutic tool in the treatment of cardiovascular-related problems $[4,9,10]$. This notion is based on the fact that accumulating evidence shows an association between gut bacteria dysbiosis and cardiovascular and metabolic diseases. For instance, the development of hypertension was recently linked to gut dysbiosis and altered levels of gut-derived metabolites [3]. Yang et al. compared the gut microbiota of normotensive Wistar Kyoto rats and spontaneously hypertensive rats (SHR), and found that SHR rats showed a decreased microbial diversity and lower colonization level of Actinobacteria. Furthermore, the Firmicute-Bacteroidetes (F/B) ratio, a marker of gut dysbiosis, have been found to be increased in SHR and in rats with angiotensin II-induced hypertension [50]. In a rat model of obstructive sleep apnea, a high-fat diet resulted in development of hypertension and in a lower butyrate production by gut microbiota. An increase in arterial blood pressure was also observed after transplantation of cecal content from hypertensive obstructive sleep apnea rats into normotensive controls [51]. Mell et al. analyzed differences in bacterial phyla of Dahl salt-sensitive rats that develop hypertension if fed a high-salt diet (S) and 
Dahl salt-resistant rats that do not develop hypertension when fed a high-salt diet (R). The $S$ rats showed increased colonization levels of S24-7 family of Bacteriodetes phyla and Veillonellaceae family of Firmicutes phyla in comparison to the R rats. After intestinal decontamination with antibiotics, the cecal content was transplanted from the $S$ rats to the $\mathrm{R}$ rats, and the other way around. Both strains were maintained on a high-salt diet. Surprisingly, the $S$ rats given the $\mathrm{R}$ rat microbiota further exacerbated hypertension. This was accompanied by a lower level of fecal bacteria of the Veillonellaceae family, increased plasma acetate and heptanoate levels, and a shorter lifespan [5].

It has been well established that there is a strong correlation between high cardiovascular risk, diabetes mellitus and metabolic syndrome. Several lines of evidence suggest that disturbances in gut microbiota composition are also present in metabolic diseases. For example, gut dysbiosis and altered mucosal immunity were found in diabetic patients [8,52]. Children with type 1 diabetes (T1D) showed decreased colonization levels of butyrate-producing bacteria and a negative correlation of the F/B ratio with the glucose level [52]. A metagenome-wide association study of gut microbiota in type 2 diabetes showed gut dysbiosis accompanied by an increase in membrane transport of sugars and branched-chain amino acid, increased methane metabolism, xenobiotic degradation, and sulfate reduction. By contrast, a decrease in the level of bacterial chemotaxis, flagellar assembly, butyrate biosynthesis and metabolism of cofactors and vitamins was found [8]. Studies in animals showed that gut colonization in early life plays an important role in the regulation of fat deposition and development of metabolic syndrome [53]. Furthermore, it was reported that the F/B ratio positively correlates with body weight and is significantly increased in obese people and mice [54-56]. On the other hand, some studies found no difference or a decreased F/B ratio in obese patients compared to lean controls [57-59]. Further evidence is needed to clarify these discrepancies. The role of gut microbiota in the development of obesity was studied in germ-free mice. Despite a high-fat, sugar-rich diet, germ-free mice remained lean [60]. Additionally, fecal transplantation from controls to germ-free mice resulted in a $60 \%$ increase in body fat and insulin resistance within two weeks [61]. Toll-like receptor 5 (TLR5) expressed by the gut mucosa was suggested to play a role in metabolic syndrome. TLR5-deficient mice showed many features of metabolic syndrome together with gut dysbiosis. Furthermore, transplantation of cecal content from TLR5-deficient mice into wild-type germ-free mice resulted in development of metabolic syndrome [62].

\section{Gut Bacteria-Derived Molecules and the Circulatory System}

Mammalian gut microbiota is a source of a wide range of metabolites. Gut bacteria metabolize carbohydrates, proteins, fat and many other compounds that enter the intestines with food and from hepato-enteric circulation. This includes short-chain fatty acids, alcohols, aldehydes, amines, aromatic derivatives of amino acids (phenols, cresols, indoles), as well as gases, such as $\mathrm{H}_{2} \mathrm{~S}$, methane, $\mathrm{NO}$ and CO. Physiological and pathological roles of the gut-derived metabolites are the topic of several reviews $[2,33,34,42,63,64]$. Here we will focus on the gut-derived molecules that may be involved in the regulation of the circulatory system and in the etiology of cardiovascular diseases.

\subsection{Hydrogen Sulfide}

\subsubsection{Gut Bacteria and Hydrogen Sulfide}

SRB are ubiquitous members of mammalian colon [65]. The dominant genera are Desulfovibrio (D. piger, D. desulfuricans), Desulfobacter, Desulfobulbus and Desulfotomaculu [19]. Two substrates are essential for $\mathrm{SRB}$ to produce $\mathrm{H}_{2} \mathrm{~S}$, i.e., a sulfate and an electron donor for the sulfate reduction. Sulfate-rich diet results in increased growth of $D$. piger and increased $\mathrm{H}_{2} \mathrm{~S}$ production in the colon of humans and mice [66,67]. D. piger may also utilize sulfated glycans. Since SRB are nonsaccharolytic, they co-colonize Bacteroides thetaiotaomicron which liberate sulfate from sulfomucin and mucopolysacharides via sulfatases $[66,68]$. The presence of $D$. piger positively correlates with the level of the Actinobacterium, Collinsella aerofaciens. It is hypothesized that SRB promote the C. aerofaciens 
sugar fermentation by removing the products $\left(\mathrm{H}_{2}\right.$, lactate, formate), which serve as electron donors for the sulfate reduction [66].

$\mathrm{SRB}$ represent a nonenzymatic source of $\mathrm{H}_{2} \mathrm{~S}$ in the mammals gut. The second source is enzymatic generation performed by either gut bacteria or colonic tissues. Several anaerobic bacterial strains (Escherichia coli, Salmonella enterica, Clostridia and Enterobacter aerogenes) convert cysteine to $\mathrm{H}_{2} \mathrm{~S}$, pyruvate and ammonia by cysteine desulfhydrase $[69,70]$. In addition, gut bacteria may produce $\mathrm{H}_{2} \mathrm{~S}$ by sulfite reduction. Sulfite reductase is present in many species such as E. coli, Salmonella, Enterobacter, Klebsiella, Bacillus, Staphylococcus, Corynebacterium, and Rhodococcus [71]. The generation or utilization of $\mathrm{H}_{2} \mathrm{~S}$ in reactions catalyzed by sulfite reductase is dependent on redox potential [72]. Finally, mammalian tissues can synthesize $\mathrm{H}_{2} \mathrm{~S}$ from L-cysteine and L-homocysteine in reactions catalyzed by cystathionine beta-synthase (CBS), cystathionine gamma-lyase (CSE) and 3-mercaptopyruvate sulfurtransferase (3-MST). CSE and CBS were reported to be present in the gastrointestinal tract of rodents and humans [73-76], while the CSE seems to be a major source of the gut $\mathrm{H}_{2} \mathrm{~S}$ generation [77].

The total sulfide concentration in the luminal content of the large intestine has been reported to be in the range of $0.2-3.4 \mathrm{mmol} / \mathrm{L}$ in humans [78], rats [79] and mice [80]. It needs to be stressed that the feces of humans and rodents have a large binding capacity, and less than $8 \%$ of total sulfide was found to be in a free form $[79,81]$. Interestingly, colonic epithelial cells are more efficient in converting sulfide into thiosulfate than other tissues [82]. In the study of Levitt et al., the analysis of cecal venous blood after intracecal infusion of radioactive $\mathrm{H}_{2} \mathrm{~S}$ in rats revealed that all absorbed $\mathrm{H}_{2} \mathrm{~S}$ had been oxidized to thiosulfate [83].

The proportion of $\mathrm{H}_{2} \mathrm{~S}$ synthesis derived from bacteria and colonic tissue was examined by Flannigan et al. [84]. They have found that fecal samples of germ-free mice contained half of $\mathrm{H}_{2} \mathrm{~S}$ in comparison to feces of controls. Furthermore, it was shown that the absence of vitamin $\mathrm{B}_{6}$, a CSE and CBS cofactor, in the diet resulted in a $50 \%$ reduction of fecal $\mathrm{H}_{2} \mathrm{~S}$. The deficiency of vitamin $\mathrm{B}_{6}$ in the diet significantly reduced fecal $\mathrm{H}_{2} \mathrm{~S}$ levels, likely due to the inhibition of enzymatic $\mathrm{H}_{2} \mathrm{~S}$ synthesis in colonic tissues. Interestingly, after six weeks of a vitamin $\mathrm{B}_{6}$-deficient diet, the fecal $\mathrm{H}_{2} \mathrm{~S}$ levels returned to the same levels as in controls. This suggests that the $\mathrm{H}_{2} \mathrm{~S}$ generation in the gut of germ-free mice was shifted towards nonenzymatic pathways by increasing the SRB activity [84].

Shen et al. showed that germ-free mice exhibited decreased levels of free $\mathrm{H}_{2} \mathrm{~S}$ in inferior vena cava blood plasma and in gastrointestinal tissues, and reduced bound sulfane sulfur levels in plasma, adipose tissue and lung tissue. Furthermore, the activity of CSE was significantly lower, whereas the level of L-cysteine, a substrate for $\mathrm{H}_{2} \mathrm{~S}$ synthesis, was markedly elevated in gastrointestinal and extraintestinal tissues (aorta, liver, and kidney) of germ-free mice compared to control mice [12].

In our studies, rats treated with neomycin (an antibiotic that does not cross the GBB and is used for intestinal decontamination in liver failure patients to reduce microbiota-produced $\mathrm{NH}_{3}$ ) exhibited significantly decreased levels of thiosulfate and sulfane sulfur, products of $\mathrm{H}_{2} \mathrm{~S}$ oxidation, in portal vein blood plasma but not in peripheral blood plasma [11]. Furthermore, we found that intracolonic administration of $\mathrm{Na}_{2} \mathrm{~S}$ ( $\mathrm{a} \mathrm{H}_{2} \mathrm{~S}$ donor) increases portal blood levels of thiosulfate and sulfane sulfur, while no such significant effect was observed in peripheral blood. These findings imply that the liver may buffer the thiosulfate and sulfane sulfur pools in the organism, and suggest that systemic effects of colon-derived $\mathrm{H}_{2} \mathrm{~S}$ and/or its derivatives may be in part due to some liver-dependent mechanisms [11].

Several studies investigated the effect of intestinal $\mathrm{H}_{2} \mathrm{~S}$ on gut functions. On the one hand, it has been suggested that high colonic $\mathrm{H}_{2} \mathrm{~S}$ levels may be responsible for colonic inflammation and cancer $[73,85]$. On the other hand, recent studies suggest that colonic epithelial cells are well-adapted to the $\mathrm{H}_{2} \mathrm{~S}$-rich environment, and that $\mathrm{H}_{2} \mathrm{~S}$ plays a beneficial role in the protection of the GBB $[27,86,87]$. First, it has been proposed that $\mathrm{H}_{2} \mathrm{~S}$ may serve as an energy source for colonic epithelial cells, since the oxidation of gut $\mathrm{H}_{2} \mathrm{~S}$ results in ATP formation [87]. Second, Motta et al. reported that $\mathrm{H}_{2} \mathrm{~S}$ promotes colonic mucus production and integrity of microbiota biofilms [86]. Third, gut dysbiosis induced by chronic administration of nonsteroidal anti-inflammatory drugs was reversed by exogenous $\mathrm{H}_{2} \mathrm{~S}$ [88]. 


\subsubsection{Hydrogen Sulfide in the Circulatory System}

Many studies describe the effects of $\mathrm{H}_{2} \mathrm{~S}$ in the circulatory system, which have been thoroughly reviewed elsewhere [89-93]. In short, $\mathrm{H}_{2} \mathrm{~S}$ is synthetized in various tissues involved in circulatory system homeostasis, including the heart, blood vessels, kidneys and the brain, by CSE and CBS. Depending on the methods employed, the estimated concentration of $\mathrm{H}_{2} \mathrm{~S}$ in the blood and other tissues has been reported to be within the range of 30 and $200 \mu \mathrm{mol} / \mathrm{L}$ [93]. However, recent studies suggest that physiological concentration of $\mathrm{H}_{2} \mathrm{~S}$ in cardiovascular tissues is in nanomolar range [94], in contrast to millimolar concentrations in the intestines [78-80]. Administration of $\mathrm{H}_{2} \mathrm{~S}$ donors produces a decrease in arterial blood pressure, which appears to depend mostly on vasodilation, but the effect may be dose- and species-specific $[11,26,89-95]$. The mechanisms behind the $\mathrm{H}_{2} \mathrm{~S}$-mediated vasodilation are not clear. One of the postulated theories is an opening of ATP-sensitive potassium channels [89]. In addition to its hemodynamic effects, $\mathrm{H}_{2} \mathrm{~S}$ has been shown to produce cardioprotective, proangiogenic and cytoprotective effects, and disturbances in $\mathrm{H}_{2} \mathrm{~S}$ homeostasis have been suggested to be involved in the etiology of cardiovascular and metabolic diseases [90,91,95-97], (Figure 1). Therefore, it is not surprising that $\mathrm{H}_{2} \mathrm{~S}$ donors have attracted a great deal of attention as potential drugs. Although $\mathrm{H}_{2} \mathrm{~S}$-based balneotherapy has been practiced for centuries, there is still no solid evidence to support the use of $\mathrm{H}_{2} \mathrm{~S}$ donors in clinical practice. At present, experimental and clinical studies are being performed to evaluate the therapeutic potential of several $\mathrm{H}_{2} \mathrm{~S}$ donors, in particular in cardiovascular and gastrointestinal diseases [97].

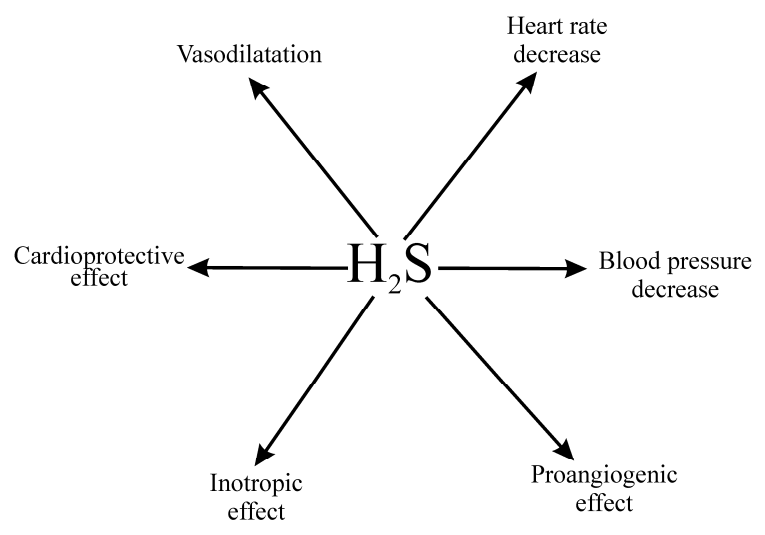

Figure 1. Major cardiovascular effects of hydrogen sulfide donors $\left(\mathrm{H}_{2} \mathrm{~S}\right.$, ref.: $\left.[11,25,26,89-93,95,97]\right)$.

It needs to be noted that biological effects of $\mathrm{H}_{2} \mathrm{~S}$ may depend on its interaction with $\mathrm{NO}$, and formation of new molecules, such as $S$-nitrosothiols. Interactions of $\mathrm{NO}$ and $\mathrm{H}_{2} \mathrm{~S}$ have been elegantly reviewed elsewhere [89]. Furthermore, $\mathrm{H}_{2} \mathrm{~S}$ is rapidly oxidized into thiosulfates and other products $[11,79,81-83]$. It is likely that both $\mathrm{H}_{2} \mathrm{~S}$ and products of its oxidation contribute to the regulation of the circulatory system.

\subsubsection{Cardiovascular Effects of the Gut-Derived Hydrogen Sulfide}

The studies on the role of $\mathrm{H}_{2} \mathrm{~S}$ in the circulatory system have thus far focused on the effects of $\mathrm{H}_{2} \mathrm{~S}$ produced enzymatically by various tissues. Strikingly, although colon microbiota represents the greatest source of $\mathrm{H}_{2} \mathrm{~S}$ in the body, the effects of colon-derived $\mathrm{H}_{2} \mathrm{~S}$ on the circulatory system have not been studied. In our laboratory, we examined the effects of increased availability of $\mathrm{H}_{2} \mathrm{~S}$ in the colon on rat hemodynamics. Intracolonic administration of $\mathrm{Na}_{2} \mathrm{~S}\left(\mathrm{a} \mathrm{H}_{2} \mathrm{~S}\right.$ donor) exerted a potent, long-lasting hypotensive effect which persisted several times longer than previously reported after parenteral infusions ( $>90 \mathrm{~min}$ ). Interestingly, hypertensive rats showed a more pronounced decrease in arterial blood pressure than normotensive rats. Besides, rats treated with neomycin showed significantly decreased levels of thiosulfate and sulfane sulfur, and a tendency for greater hypotensive response to 
$\mathrm{Na}_{2} \mathrm{~S}$. These data suggest that the gut-derived $\mathrm{H}_{2} \mathrm{~S}$ may produce systemic effects, and that changes in colonic $\mathrm{H}_{2} \mathrm{~S}$ homeostasis may be associated with hypertension. In our study, the hypotensive effect was most probably due to peripheral vasodilation and a decrease in heart rate. In contrast, local changes in intestinal blood flow were not a likely cause of the $\mathrm{H}_{2} \mathrm{~S}$-dependent hypotension. The hemodynamic effects of intracolonic $\mathrm{H}_{2} \mathrm{~S}$ donor were accompanied by increases in portal but not peripheral blood levels of $\mathrm{H}_{2} \mathrm{~S}$ oxidation products [11]. Therefore, it seems that the systemic effects of the gut $\mathrm{H}_{2} \mathrm{~S}$ were produced by either some liver-dependent mechanisms or by the effects of colonic $\mathrm{H}_{2} \mathrm{~S}$ on the enteric nervous system (Figure 2). All in all, our findings support previous evidence on the hypotensive effect of $\mathrm{H}_{2} \mathrm{~S}$ and/or its derivatives, and at the same time provide new data implying a role of gut-bacteria-derived $\mathrm{H}_{2} \mathrm{~S}$ in blood pressure control.

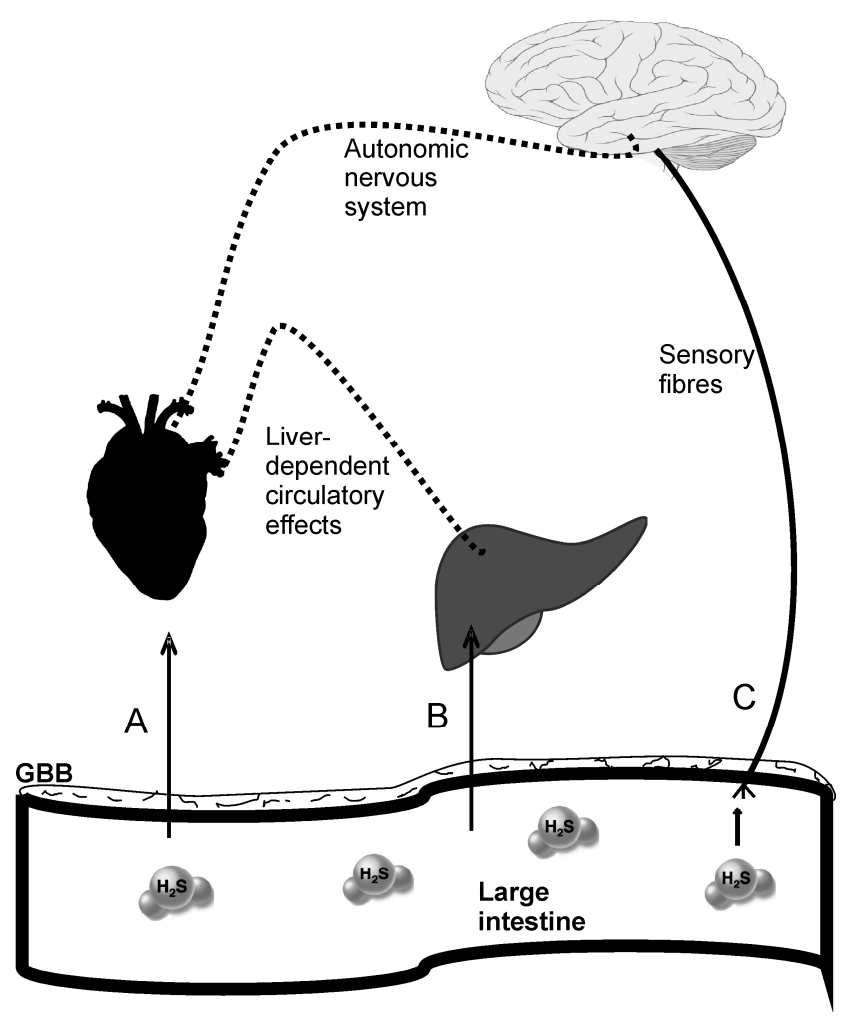

Figure 2. Postulated pathways of cardiovascular actions of gut-bacteria-derived hydrogen sulfide and its derivatives $\left(\mathrm{H}_{2} \mathrm{~S}\right)$. (A) $\mathrm{H}_{2} \mathrm{~S}$ crosses the gut-blood barrier (GBB), bypasses the liver (rectal plexuses), and targets the heart and blood vessels; (B) $\mathrm{H}_{2} \mathrm{~S}$ crosses the GBB and affects liver functions associated with the circulatory system homeostasis; (C) $\mathrm{H}_{2} \mathrm{~S}$ stimulates sensory fibers of the enteric nervous system that project to the brain centers controlling the circulatory system via the autonomic nervous system.

\subsection{Nitric Oxide}

Nitric oxide (NO) is one of the most studied biological transmitters. It plays a significant role in numerous biological systems, including the circulatory system. Intriguingly, as mentioned above, some evidence suggests that $\mathrm{NO}$ interacts with $\mathrm{H}_{2} \mathrm{~S}$, and that this interaction may determine the final biological effects of both gaseous transmitters $[89,98,99]$.

Several pathways of NO formation in the mammalian gastrointestinal tract have been proposed. The first is the nitrate-nitrite-NO pathway. Nitrate is reduced by commensal mouth bacteria to nitrite [100], which is further reduced by gut bacteria, either by nonenzymatic acidic reduction [101] or by nitrite reductases [102]. Finally, gut mucosa express NO synthase which synthetize NO's converting of L-arginine to L-citrullin [103]. It has also been found that the probiotic strains Lactobacillus and 
Bifidobacterium play a role in the intestinal production of $\mathrm{NO}$ by decreasing gut $\mathrm{pH}$ which increases nonenzymatic nitrite reduction [104]. In contrast, Desulfovibrio vulgaris convert NO to nitrates [105].

The role of NO in physiology and pathology of the gastrointestinal system [106-109] and the cardiovascular system [110-114] was reviewed elsewhere. However, the role of the gut-derived $\mathrm{NO}$ in the circulatory system homeostasis remains obscure. Similar to $\mathrm{H}_{2} \mathrm{~S}$, the circulatory effects of NO were mostly evaluated in the context of its enzymatic production by various tissues. However, Briskey et al. proposed a role of nitrification/denitrification pathway in the regulation of mammalian homeostasis [115]. Dependent on the redox state, E. coli and Lactobacillus plantarum reduce nitrites to ammonia (denitrification) [116] or ammonia is oxidized by Nitrosomonas back to nitrite (nitrification) [117]. Dysregulation of this pathway can lead to pathological accumulation of gut-derived ammonia or nitrite, gut dysbiosis and related cardiovascular problems [118-120]. A limitation of this hypothesis is that the presence of ammonia-oxidizing bacteria and archaea is described only in soil, water and plants [121].

\subsection{Carbon Monoxide}

A number of studies have shown the importance of the roles played by carbon monoxide (CO) in the circulatory system. Similar to $\mathrm{NO}$ and $\mathrm{H}_{2} \mathrm{~S}, \mathrm{CO}$ has been found to exert vasorelaxant and cardiac protection effects $[122,123]$. $\mathrm{CO}$ is produced in a reaction catalyzed by the enzyme heme oxygenase (HO). Inducible $\mathrm{HO}$ (HO-1) and constitutive $\mathrm{HO}$ (HO-2) are mostly recognized for endogenous $\mathrm{CO}$ production in mammalian tissues. In the gastrointestinal system $\mathrm{CO}$ may be produced by gut mucosa which expresses HO-1. Furthermore, Onyiah et al. reported that also gut microbiota (E. coli) express HO homologs [124] and induce colonic expression of HO-1 in mice [125]. The possible effects of gut-derived $\mathrm{CO}$ on systemic circulation remain to be elucidated.

\subsection{Methane}

The mammalian gut is colonized by methanogenic archeaea: Methanobacteriales, Methanococcales, Methanomicrobiales, Methanosarcinales, Methanopyrales, Methanocellales, Methanomassiliicoccales [2]. In human gut, the dominant methanogen is Methaninobrevibacter smithii. According to substrate utilization, there are three types of methanogens [126]: (i) The most common are hydrogenotrophs, which use $\mathrm{H}_{2}$ or formate as an electron donor for $\mathrm{CO}_{2}$ reduction [127]; (ii) Methylotrophs convert methylated compounds (methanol, methylamines and methyl-sulfides) by substrate-specific methyltransferases into methane [128]; and (iii) Acetotrophs produce methane utilizing acetate [129]. Methane may also be produced by certain Clostiridium and Bacteroides species [130].

Interestingly, sulfate reduction and methanogenesis compete for the mutual substrate, which is $\mathrm{H}_{2}$. The methanogenesis/sulfate reduction ratio is dependent on substrate availability, thermodynamics and $\mathrm{pH}$. In human colon, the ratio is in the favor of methanogenesis, due to neutral $\mathrm{pH}$ of stool and low sulfate levels in diet. However, in certain conditions, such as high availability of sulfate substrates in a diet (bread, beer, wine) and hypochlorhydria, sulfate reduction may become the major process [131,132].

The physiological levels of methane in the mammalian organism have not yet been determined [133]. Breath tests show that $30 \%-60 \%$ of healthy individuals produce gaseous methane [134-136]. As in the case of the gut-derived $\mathrm{H}_{2} \mathrm{~S}$, methane metabolism was mostly studied in association with gastrointestinal problems, such as constipation, diarrhea and irritable bowel syndrome [64,137-142].

Some studies suggest that altered methane metabolism may also play a role in cardiovascular and metabolic diseases. Methanogen growth was positively correlated with the development of obesity and diabetes $[8,143,144]$. Furthermore, it has been found that exogenous methane may reduce oxidative and nitrosative stress in animal model of ischemia-reperfusion injury [63]. 


\subsection{Trimethylamine}

The production and utilization of methylamines, in particular trimethylamines, by gut bacteria has recently attracted a lot of attention. This is because several clinical studies showed a positive correlation between elevated plasma levels of trimethylamine $N$-oxide (TMAO) and an increased risk for adverse cardiovascular events. Methylamines are bacterial products of dietary choline and carnitine [42]. Several bacterial species were reported to participate in intestinal metabolism of methylamines including: Anaerococcus hydrogenalis, Clostridium asparagiforme, Clostridium hathewayi, Clostridium sporogenes, Escherichia fergusonii, Proteus penneri, Providencia rettgeri and Edwardsiella tarda [145]. The blood concentration of TMAO was reported to be in the range of $0.5-5 \mu \mathrm{mol} / \mathrm{L}$ in healthy individuals and rodents [42].

Some studies suggest that TMAO may be a causative link between the diet, gut bacteria and cardiovascular diseases. For example, it has been found that TMAO augments heart failure in mice, plays a role in the development of atherosclerosis by modulating cholesterol and sterol metabolism [146], and prolongs the hypertensive effect of angiotensin II [147], a key hormone in circulatory system homeostasis. On the other hand, it has been reported that vascular injury and oxidative stress were reduced after L-carnitine rich diet, which resulted in elevated TMA and TMAO plasma levels [148]. In addition, an increase in TMAO blood level in rats from 0.6 to $60 \mu \mathrm{mol} / \mathrm{L}$ for two weeks did not produce any apparent toxic effect [147]. Finally, it is worth noting that high concentrations of TMAO $(100 \mu \mathrm{mol} / \mathrm{L}$ and higher $)$ are found in saltwater fish, the consumption of which has been considered to have a beneficial effect on the circulatory system [42]. Further studies are needed to assess the physiological and pathological importance of TMAO in humans.

\subsection{Indole}

Various bacteria, more than 85 species, can metabolize trypthophane and form indole. For example, the conversion of tryptophan into indole, pyruvate and ammonia is catalyzed by tryptophanase in E. coli [149]. Indole was detected in mammalian feces [150-152], and gut bacteria produce indole presumably by enzymes homologous to tryptophanases [33]. In the gut, indole is either oxidized by bacterial oxygenases or by cytochrome P450 to form indoxyl, which is further sulfonated in the liver to indoxyl sulfate (IS) and excreted with urine [149].

Indole production was studied mostly in association with the regulation of bacterial physiology. It was reported that indole regulates spore formation, drug resistance, virulence, plasmid stability, and biofilm formation in several bacteria $[149,153]$. The role of indole in the regulation of mammalian homeostasis remains unclear. Cardiorenal syndrome, a combination of cardiovascular and kidney disorders, chronic kidney failure, and vascular remodeling have been found to be positively associated with increased concentration of circulating IS [154-157]. Furthermore, IS blood level may serve as a predictor of cardiovascular events and mortality in chronic kidney patients $[155,156]$. Some experimental studies in rats suggest that a decrease in IS level inhibits the progression of cardiomyopathy and chronic kidney failure [158-160]. Other studies imply that indole may protect the GBB integrity [161] and have anti-inflammatory properties [161,162].

\subsection{Ammonia}

A great pool of ammonia $\left(\mathrm{NH}_{3}\right)$ is formed in the mammalian gut by several bacterial species and gastrointestinal tissues [36]. In fact, the degradation of urea by gut microbiota ureases $(\sim 7 \mathrm{~g} / \mathrm{day})$ is the source of around $50 \%$ of total $\mathrm{NH}_{3}$ in the body [163]. The $\mathrm{NH}_{3}$ production rate in the human gut is 4-10 g/day [36]. Unbound $\mathrm{NH}_{3}$ is either excreted with feces ( 5-25 $\left.\mu \mathrm{g} / \mathrm{g}\right)$ [34] or retransformed into amino acids by gut microbiota, or absorbed through the GBB. The plasmatic concentration of free $\mathrm{NH}_{3}$ in healthy individuals is $\sim 35 \mu \mathrm{mol} / \mathrm{L}$ [36]. Circulating $\mathrm{NH}_{3}$ can be either converted into urea or glutamine in the liver or excreted with urine (2-3 mg/day) [163]. 
Liver disorders associated with hyperammonemia and related neurotoxic effects are well described, and patients with liver failure are often treated with antibiotics, such as neomycin, to decontaminate the intestines and decrease bacterial production of $\mathrm{NH}_{3}$. Interestingly, there is some evidence that $\mathrm{NH}_{3}$ may affect the control of the circulatory system. For example, a positive inotropic effect of $\mathrm{NH}_{3}$ on isolated rat hearts was reported [164]. Moreover, it has been found that $\mathrm{NH}_{3}$ inhalation in healthy adults results in cerebrovascular vasodilatation without affecting the arterial blood pressure [165]. Finally, patients with HF show increased plasma levels of $\mathrm{NH}_{3}[119,120]$.

\section{Conclusions}

Several lines of evidence suggest that gut bacteria may affect the functioning of the circulatory system. Trimethylamine $N$-oxide (TMAO), a gut-bacteria-derived molecule, has recently emerged as a new diagnostic marker of increased cardiovascular risk, and gut dysbiosis has been found in cardiovascular and metabolic diseases. Sulfate-reducing bacteria are abundant in the mammalian colon, producing significant amounts of sulfur compounds, including $\mathrm{H}_{2} \mathrm{~S}$. Despite a large number of studies on $\mathrm{H}_{2} \mathrm{~S}$ in the circulatory system, there is scant data on the effects of gut-derived sulfur compounds. Further research on gut sulfate-reducing bacteria and their products is needed as they may become a therapeutic target in cardiovascular diseases.

Acknowledgments: Research associated with this paper was supported by the Medical University of Warsaw and National Science Centre, Poland; grants 2016/21/B/NZ5/02544.

Conflicts of Interest: The authors declare no conflict of interest.

\section{References}

1. Kelly, C.R.; Kahn, S.; Kashyap, P.; Laine, L.; Rubin, D.; Atreja, A.; Moore, T.; Wu, G. Update on Fecal Microbiota Transplantation 2015: Indications, Methodologies, Mechanisms, and Outlook. Gastroenterology 2015, 149, 223-237. [CrossRef] [PubMed]

2. Gaci, N.; Borrel, G.; Tottey, W.; O'Toole, P.W.; Brugere, J.F. Archaea and the human gut: New beginning of an old story. World J. Gastroenterol. 2014, 20, 16062-16078. [CrossRef] [PubMed]

3. Honour, J.W. Historical perspective: Gut dysbiosis and hypertension. Physiol. Genomics. 2015, 47, 443-446. [CrossRef] [PubMed]

4. John, G.K.; Mullin, G.E. The Gut Microbiome and Obesity. Curr. Oncol. Rep. 2016, 18, 45. [CrossRef] [PubMed]

5. Mell, B.; Jala, V.R.; Mathew, A.V.; Byun, J.; Waghulde, H.; Zhang, Y.; Haribabu, B.; Vijay-Kumar, M.; Pennathur, S.; Joe, B. Evidence for a link between gut microbiota and hypertension in the Dahl rat. Physiol. Genom. 2015, 47, 187-197. [CrossRef] [PubMed]

6. Parekh, P.J.; Balart, L.A. Ammonia and Its Role in the Pathogenesis of Hepatic Encephalopathy. Clin. Liver Dis. 2015, 19, 529-537. [CrossRef] [PubMed]

7. Zhang, Y.J.; Li, S.; Gan, R.Y.; Zhou, T.; Xu, D.P.; Li, H.B. Impacts of Gut Bacteria on Human Health and Diseases. Int. J. Mol. Sci. 2015, 16, 7493-7519. [CrossRef] [PubMed]

8. Wang, J.; Qin, J.; Li, Y.; Cai, Z.; Li, S.; Zhu, J.; Zhang, F.; Liang, S.; Zhang, W.; Guan, Y.; et al. A metagenome-wide association study of gut microbiota in type 2 diabetes. Nature 2012, 490, 55-60.

9. Cammarota, G.; Ianiro, G.; Bibbò, S.; Gasbarrini, A. Fecal microbiota transplantation a new old kid on the block for the management of gut microbiota-related disease. J. Clin. Gastroenterol. 2014, 48, S80-S84. [CrossRef] [PubMed]

10. Parekh, P.J.; Arusi, E.; Vinik, A.I.; Johnson, D.A. The role and influence of gut microbiota in pathogenesis and management of obesity and metabolic syndrome. Front. Endocrinol. (Lausanne) 2014, 5. [CrossRef] [PubMed]

11. Tomasova, L.; Jurkowska, H.; Wrobel, M.; Huc, T.; Ondrias, K.; Ostaszewski, R.; Ufnal, M. Intracolonic hydrogen sulfide lowers blood pressure in rats. Nitric Oxide 2016, 60, 50-58. [CrossRef] [PubMed]

12. Shen, X.; Carlstrom, M.; Borniquel, S.; Jadert, C.; Kevil, C.G.; Lundberg, J.O. Microbial regulation of host hydrogen sulfide bioavailability and metabolism. Free Radic. Biol. Med. 2013, 60, 195-200. [CrossRef] [PubMed] 
13. Raiswell, R.; Canfield, D.E. The iron biogeochemical cycle past and present. Geochem. Perspect. 2012, 1, 1-232. [CrossRef]

14. Schopf, J.W. Geological evidence of oxygenic photosynthesis and the biotic response to the 2400-2200 Ma "great Oxidation Event". Biochemistry (Mosc.) 2014, 79, 165-177. [CrossRef] [PubMed]

15. Olson, K.R.; Straub, K.D. The role of hydrogen sulfide in evolution and the evolution of hydrogen sulfide in metabolism and signaling. Physiology (Bethesda) 2016, 31, 60-72. [CrossRef] [PubMed]

16. Parker, E.T.; Cleaves, H.J.; Callahan, M.P.; Dworkin, J.P.; Glavin, D.P.; Lazcano, A.; Bada, J.L. Prebiotic Synthesis of Methionine and Other Sulfur-Containing Organic Compounds on the Primitive Earth: A Contemporary Reassessment Based on an Unpublished 1958 Stanley Miller Experiment. Orig. Life Evol. Biosph. 2011, 41, 201-212. [CrossRef] [PubMed]

17. Parker, E.T.; Cleaves, H.J.; Dworkin, J.P.; Glavin, D.P.; Callahan, M.; Aubrey, A.; Lazcano, A.; Bada, J.L. Primordial synthesis of amines and amino acids in a 1958 Miller H 2S-rich spark discharge experiment. Proc. Natl. Acad. Sci. USA 2011, 108, 5526-5531. [CrossRef] [PubMed]

18. Wacey, D.; Kilburn, M.R.; Saunders, M.; Cliff, J.; Brasier, M.D. Microfossils of sulphur-metabolizing cells in 3.4-billion-year-old rocks of Western Australia. Nat. Geosci. 2011, 4, 698-702. [CrossRef]

19. Rabus, R.; Venceslau, S.S.; Wöhlbrand, L.; Voordouw, G.; Wall, J.D.; Pereira, I.A.C. A Post-Genomic View of the Ecophysiology, Catabolism and Biotechnological Relevance of Sulphate-Reducing Prokaryotes. Adv. Microb. Physiol. 2015, 66, 55-321. [PubMed]

20. Abe, K.; Kimura, H. The possible role of hydrogen sulfide as an endogenous neuromodulator. J. Neurosci. 1996, 16, 1066-1071. [PubMed]

21. Tomasova, L.; Pavlovicova, M.; Malekova, L.; Misak, A.; Kristek, F.; Grman, M.; Cacanyiova, S.; Tomasek, M.; Tomaskova, Z.; Perry, A.; et al. Effects of AP39, a novel triphenylphosphonium derivatised anethole dithiolethione hydrogen sulfide donor, on rat haemodynamic parameters and chloride and calcium $\mathrm{CaV}_{\mathrm{V}} 3$ and RyR2 channels. Nitric Oxide 2015, 46, 131-144. [CrossRef] [PubMed]

22. Drobna, M.; Misak, A.; Holland, T.; Kristek, F.; Grman, M.; Tomasova, L.; Berenyiova, A.; Cacanyiova, S.; Ondrias, K. Captopril partially decreases the effect of $\mathrm{H}_{2} \mathrm{~S}$ on rat blood pressure and inhibits $\mathrm{H}(2) \mathrm{S}$-induced nitric oxide release from S-nitrosoglutathione. Physiol. Res. 2014, 64, 479-486. [PubMed]

23. Lohninger, L.; Tomasova, L.; Praschberger, M.; Hintersteininger, M.; Erker, T.; Gmeiner, B.M.; Laggner, H. Hydrogen sulphide induces HIF-1alpha and Nrf2 in THP-1 macrophages. Biochimie 2015, 112, 187-195. [CrossRef] [PubMed]

24. Polhemus, D.J.; Lefer, D.J. Emergence of hydrogen sulfide as an endogenous gaseous signaling molecule in cardiovascular disease. Circ. Res. 2014, 114, 730-737. [CrossRef] [PubMed]

25. Sikora, M.; Pham, K.; Ufnal, M. Hypotensive effect of S-adenosyl-L-methionine in hypertensive rats is reduced by autonomic ganglia and KATP channel blockers. Amino Acids 2016, 48, 1581-1590. [CrossRef] [PubMed]

26. Dombkowski, R.A.; Russell, M.J.; Olson, K.R. Hydrogen sulfide as an endogenous regulator of vascular smooth muscle tone in trout. Am. J. Physiol. Regul. Integr. Comp. Physiol. 2004, 286, R678-R685. [CrossRef] [PubMed]

27. Wallace, J.L. Physiological and pathophysiological roles of hydrogen sulfide in the gastrointestinal tract. Antioxid. Redox Signal. 2010, 12, 1125-1133. [CrossRef] [PubMed]

28. Yatsunenko, T.; Rey, F.E.; Manary, M.J.; Trehan, I.; Dominguez-Bello, M.G.; Contreras, M.; Magris, M.; Hidalgo, G.; Baldassano, R.N.; Anokhin, A.P.; et al. Human gut microbiome viewed across age and geography. Nature 2012, 486, 222-227. [CrossRef] [PubMed]

29. David, L.A.; Maurice, C.F.; Carmody, R.N.; Gootenberg, D.B.; Button, J.E.; Wolfe, B.E.; Ling, A.V.; Devlin, A.S.; Varma, Y.; Fischbach, M.A.; et al. Diet rapidly and reproducibly alters the human gut microbiome. Nature 2014, 505, 559-563. [CrossRef] [PubMed]

30. Dominguez-Bello, M.G.; Costello, E.K.; Contreras, M.; Magris, M.; Hidalgo, G.; Fierer, N.; Knight, R. Delivery mode shapes the acquisition and structure of the initial microbiota across multiple body habitats in newborns. Proc. Natl. Acad. Sci. USA 2010, 107, 11971-11975. [CrossRef] [PubMed]

31. Liu, Z.; Roy, N.C.; Guo, Y.; Jia, H.; Ryan, L.; Samuelsson, L.; Thomas, A.; Plowman, J.; Clerens, S.; Day, L.; Young, W. Human breast milk and infant formulas differentially modify the intestinal microbiota in human infants and host physiology in rats. J. Nutr. 2016, 146, 191-199. [CrossRef] [PubMed] 
32. Hermann-Bank, M.L.; Skovgaard, K.; Stockmarr, A.; Larsen, N.; Mølbak, L. The Gut Microbiotassay: A high-throughput qPCR approach combinable with next generation sequencing to study gut microbial diversity. BMC Genom. 2013, 14. [CrossRef] [PubMed]

33. Donia, M.S.; Fischbach, M.A. Small molecules from the human microbiota. Science 2015, 349, 1254766. [CrossRef] [PubMed]

34. Verbeke, K.A.; Boobis, A.R.; Chiodini, A.; Edwards, C.A.; Franck, A.; Kleerebezem, M.; Nauta, A.; Raes, J.; Van Tol, E.A.F.; Tuohy, K.M. Towards microbial fermentation metabolites as markers for health benefits of prebiotics. Nutr. Res. Rev. 2015, 28, 42-66. [CrossRef] [PubMed]

35. Lam, V.; Su, J.; Hsu, A.; Gross, G.J.; Salzman, N.H.; Baker, J.E. Intestinal Microbial Metabolites Are Linked to Severity of Myocardial Infarction in Rats. PLoS ONE 2016, 11, e0160840. [CrossRef] [PubMed]

36. Oleskin, A.V.; Shenderov, B.A. Neuromodulatory effects and targets of the SCFAs and gasotransmitters produced by the human symbiotic microbiota. Microb. Ecol. Health Dis. 2016, 27, 30971. [CrossRef] [PubMed]

37. Ufnal, M. Essential hypertension-is erroneous receptor output to blame? Med. Hypotheses 2012, 78, 454-458. [CrossRef] [PubMed]

38. Hansen, M.K.; Krueger, J.M. Subdiaphragmatic vagotomy blocks the sleep- and fever-promoting effects of interleukin-1beta. Am. J. Physiol. 1997, 273, R1246-R1253. [PubMed]

39. Huc, T.; Pham, K.; Skrzypecki, J.; Ufnal, M. Significance of gut-blood barrier in health and disease. Eur. J. Biol. Res. 2016, 6, 193-200.

40. Bischoff, S.C.; Barbara, G.; Buurman, W.; Ockhuizen, T.; Schulzke, J.D.; Serino, M.; Tilg, H.; Watson, A.; Wells, J.M. Intestinal permeability-A new target for disease prevention and therapy. BMC Gastroenterol. 2014, 14, 189. [CrossRef] [PubMed]

41. Lekawanvijit, S. Role of gut-derived protein-bound uremic toxins in cardiorenal syndrome and potential treatment modalities. Circ. J. 2015, 79, 2088-2097. [CrossRef] [PubMed]

42. Ufnal, M.; Zadlo, A.; Ostaszewski, R. TMAO: A small molecule of great expectations. Nutrition 2015, 31, 1317-1323. [CrossRef] [PubMed]

43. Lopetuso, L.R.; Scaldaferri, F.; Bruno, G.; Petito, V.; Franceschi, F.; Gasbarrini, A. The therapeutic management of gut barrier leaking: The emerging role for mucosal barrier protectors. Eur. Rev. Med. Pharmacol. Sci. 2015, 19, 1068-1076. [PubMed]

44. Perrier, C.; Corthesy, B. Gut permeability and food allergies. Clin. Exp. Allergy 2011, 41, 20-28. [CrossRef] [PubMed]

45. Sandek, A.; Swidsinski, A.; Schroedl, W.; Watson, A.; Valentova, M.; Herrmann, R.; Scherbakov, N.; Cramer, L.; Rauchhaus, M.; Grosse-Herrenthey, A.; et al. Intestinal blood flow in patients with chronic heart failure: A link with bacterial growth, gastrointestinal symptoms, and cachexia. J. Am. Coll. Cardiol. 2014, 64, 1092-1102. [CrossRef] [PubMed]

46. Sandek, A.; Bjarnason, I.; Volk, H.D.; Crane, R.; Meddings, J.B.; Niebauer, J.; Kalra, P.R.; Buhner, S.; Herrmann, R.; Springer, J.; et al. Studies on bacterial endotoxin and intestinal absorption function in patients with chronic heart failure. Int. J. Cardiol. 2012, 157, 80-85. [CrossRef] [PubMed]

47. Sandek, A.; Bauditz, J.; Swidsinski, A.; Buhner, S.; Weber-Eibel, J.; von Haehling, S.; Schroedl, W.; Karhausen, T.; Doehner, W.; Rauchhaus, M.; et al. Altered Intestinal Function in Patients With Chronic Heart Failure. J. Am. Coll. Cardiol. 2007, 50, 1561-1569. [CrossRef] [PubMed]

48. Arutyunov, G.P.; Kostyukevich, O.I.; Serov, R.A.; Rylova, N.V.; Bylova, N.A. Collagen accumulation and dysfunctional mucosal barrier of the small intestine in patients with chronic heart failure. Int. J. Cardiol. 2008, 125, 240-245. [CrossRef] [PubMed]

49. Niebauer, J.; Volk, H.D.; Kemp, M.; Dominguez, M.; Schumann, R.R.; Rauchhaus, M.; Poole-Wilson, P.A.; Andrew, J.; Coats, S.; Anker, S.D. Endotoxin and immune activation in chronic heart failure: A prospective cohort study. Lancet 1999, 353, 1838-1842. [CrossRef]

50. Yang, T.; Santisteban, M.M.; Rodriguez, V.; Li, E.; Ahmari, N.; Carvajal, J.M.; Zadeh, M.; Gong, M.; Qi, Y.; Zubcevic, J.; Sahay, B.; et al. Gut dysbiosis is linked to hypertension. Hypertension 2015, 65, 1331-1340. [CrossRef] [PubMed]

51. Durgan, D.J.; Ganesh, B.P.; Cope, J.L.; Ajami, N.J.; Phillips, S.C.; Petrosino, J.F.; Hollister, E.B.; Bryan, R.M. Role of the Gut Microbiome in Obstructive Sleep Apnea-Induced Hypertension. Hypertension 2016, 67, 469-474. [CrossRef] [PubMed] 
52. Murri, M.; Leiva, I.; Gomez-Zumaquero, J.M.; Tinahones, F.J.; Cardona, F.; Soriguer, F.; Queipo-Ortuño, M.I. Gut microbiota in children with type 1 diabetes differs from that in healthy children: A case-control study. BMC Med. 2013, 11. [CrossRef] [PubMed]

53. Wallace, J.G.; Gohir, W.; Sloboda, D.M. The impact of early life gut colonization on metabolic and obesogenic outcomes: What have animal models shown us? J. Dev. Orig. Health Dis. 2016, 7, 15-24. [CrossRef] [PubMed]

54. Armougom, F.; Henry, M.; Vialettes, B.; Raccah, D.; Raoult, D. Monitoring bacterial community of human gut microbiota reveals an increase in Lactobacillus in obese patients and Methanogens in anorexic patients. PLoS ONE 2009, 4, e7125. [CrossRef] [PubMed]

55. Ley, R.E.; Turnbaugh, P.J.; Klein, S.; Gordon, J.I. Microbial ecology: Human gut microbes associated with obesity. Nature 2006, 444, 1022-1023. [CrossRef] [PubMed]

56. Murphy, E.F.; Cotter, P.D.; Healy, S.; Marques, T.M.; O’Sullivan, O.; Fouhy, F.; Clarke, S.F.; O’Toole, P.W.; Quigley, E.M.; Stanton, C.; et al. Composition and energy harvesting capacity of the gut microbiota: Relationship to diet, obesity and time in mouse models. Gut 2010, 59, 1635-1642. [CrossRef] [PubMed]

57. Duncan, S.H.; Lobley, G.E.; Holtrop, G.; Ince, J.; Johnstone, A.M.; Louis, P.; Flint, H.J. Human colonic microbiota associated with diet, obesity and weight loss. Int. J. Obes. (Lond.) 2008, 32, 1720-1724. [CrossRef] [PubMed]

58. Schwiertz, A.; Taras, D.; Schäfer, K.; Beijer, S.; Bos, N.A.; Donus, C.; Hardt, P.D. Microbiota and SCFA in lean and overweight healthy subjects. Obesity 2010, 18, 190-195. [CrossRef] [PubMed]

59. Jumpertz, R.; Le, D.S.; Turnbaugh, P.J.; Trinidad, C.; Bogardus, C.; Gordon, J.I.; Krakoff, J. Energy-balance studies reveal associations between gut microbes, caloric load, and nutrient absorption in humans. Am. J. Clin. Nutr. 2011, 94, 58-65. [CrossRef] [PubMed]

60. Bäckhed, F.; Manchester, J.K.; Semenkovich, C.F.; Gordon, J.I. Mechanisms underlying the resistance to diet-induced obesity in germ-free mice. Proc. Natl. Acad. Sci. USA 2007, 104, 979-984. [CrossRef] [PubMed]

61. Bäckhed, F.; Ding, H.; Wang, T.; Hooper, L.V.; Gou, Y.K.; Nagy, A.; Semenkovich, C.F.; Gordon, J.I. The gut microbiota as an environmental factor that regulates fat storage. Proc. Natl. Acad. Sci. USA 2004, 101, 15718-15723. [CrossRef] [PubMed]

62. Vijay-Kumar, M.; Aitken, J.D.; Carvalho, F.A.; Cullender, T.C.; Mwangi, S.; Srinivasan, S.; Sitaraman, S.V.; Knight, R.; Ley, R.E.; Gewirtz, A.T. Metabolie syndrome and altered gut microbiota in mice lacking toll-like receptor 5. Science 2010, 328, 228-231. [CrossRef] [PubMed]

63. Boros, M.; Ghyczy, M.; Irces, D.; Varga, G.; Tokés, T.; Kupai, K.; Torday, C.; Kaszaki, J. The anti-inflammatory effects of methane. Crit. Care Med. 2012, 40, 1269-1278. [CrossRef] [PubMed]

64. Triantafyllou, K.; Chang, C.; Pimentel, M. Methanogens, methane and gastrointestinal motility. J. Neurogastroenterol. Motil. 2014, 20, 31-40. [CrossRef] [PubMed]

65. Carbonero, F.; Benefiel, A.C.; Gaskins, H.R. Contributions of the microbial hydrogen economy to colonic homeostasis. Nat. Rev. Gastroenterol. Hepatol. 2012, 9, 504-518. [CrossRef] [PubMed]

66. Rey, F.E.; Gonzalez, M.D.; Cheng, J.; Wu, M.; Ahern, P.P.; Gordon, J.I. Metabolic niche of a prominent sulfate-reducing human gut bacterium. Proc. Natl. Acad. Sci. USA 2013, 110, 13582-13587. [CrossRef] [PubMed]

67. Gibson, G.R.; Macfarlane, G.T.; Cummings, J.H. Occurrence of sulphate-reducing bacteria in human faeces and the relationship of dissimilatory sulphate reduction to methanogenesis in the large gut. J. Appl. Bacteriol. 1988, 65, 103-111. [CrossRef] [PubMed]

68. Croix, J.A.; Carbonero, F.; Nava, G.M.; Russell, M.; Greenberg, E.; Gaskins, H.R. On the relationship between sialomucin and sulfomucin expression and hydrogenotrophic microbes in the human colonic mucosa. PLOS ONE 2011, 6, e24447. [CrossRef] [PubMed]

69. Awano, N.; Wada, M.; Mori, H.; Nakamori, S.; Takagi, H. Identification and functional analysis of Escherichia coli cysteine desulfhydrases. Appl. Environ. Microbiol. 2005, 71, 4149-4152. [CrossRef] [PubMed]

70. Kumagai, H.; Sejima, S.; Choi, Y.J.; Tanaka, H.; Yamada, H. Crystallization and properties of cysteine desulfhydrase from Aerobacter aerogenes. FEBS Lett. 1975, 52, 304-307. [CrossRef]

71. Blachier, F.; Davila, A.M.; Mimoun, S.; Benetti, P.H.; Atanasiu, C.; Andriamihaja, M.; Benamouzig, R.; Bouillaud, F.; Tomé, D. Luminal sulfide and large intestine mucosa: Friend or foe? Amino Acids 2010, 39, 335-347. [CrossRef] [PubMed] 
72. Siegel, L.M.; Murphy, M.J.; Kamin, H. Reduced nicotinamide adenine dinucleotide phosphate-sulfite reductase of enterobacteria. I. The Escherichia coli hemoflavoprotein: Molecular parameters and prosthetic groups. J. Biol. Chem. 1973, 248, 251-264. [PubMed]

73. Cao, Q.; Zhang, L.; Yang, G.; Xu, C.; Wang, R. Butyrate-stimulated H2S production in colon cancer cells. Antioxid. Redox Signal. 2010, 12, 1101-1109. [CrossRef] [PubMed]

74. Distrutti, E.; Sediari, L.; Mencarelli, A.; Renga, B.; Orlandi, S.; Russo, G.; Caliendo, G.; Santagada, V.; Cirino, G.; Wallace, J.L.; et al. 5-Amino-2-hydroxybenzoic acid 4-(5-thioxo-5H-[1,2]dithiol-3yl)-phenyl ester (ATB-429), a hydrogen sulfide-releasing derivative of mesalamine, exerts antinociceptive effects in a model of postinflammatory hypersensitivity. J. Pharmacol. Exp. Ther. 2006, 319, 447-458. [CrossRef] [PubMed]

75. Martin, G.R.; McKnight, G.W.; Dicay, M.S.; Coffin, C.S.; Ferraz, J.G.P.; Wallace, J.L. Hydrogen sulphide synthesis in the rat and mouse gastrointestinal tract. Dig. Liver Dis 2010, 42, 103-109. [CrossRef] [PubMed]

76. Wallace, J.L.; Vong, L.; McKnight, W.; Dicay, M.; Martin, G.R. Endogenous and Exogenous Hydrogen Sulfide Promotes Resolution of Colitis in Rats. Gastroenterology 2009, 137, 569-578. [CrossRef] [PubMed]

77. Fiorucci, S.; Antonelli, E.; Distrutti, E.; Rizzo, G.; Mencarelli, A.; Orlandi, S.; Zanardo, R.; Renga, B.; Di Sante, M.; Morelli, A.; et al. Inhibition of hydrogen sulfide generation contributes to gastric injury caused by anti-inflammatory nonsteroidal drugs. Gastroenterology 2005, 129, 1210-1224. [CrossRef] [PubMed]

78. Magee, E.A.; Richardson, C.J.; Hughes, R.; Cummings, J.H. Contribution of dietary protein to sulfide production in the large intestine: An in vitro and a controlled feeding study in humans. Am. J. Clin. Nutr. 2000, 72, 1488-1494. [PubMed]

79. Levitt, M.D.; Springfield, J.; Furne, J.; Koenig, T.; Suarez, F.L. Physiology of sulfide in the rat colon: Use of bismuth to assess colonic sulfide production. J. Appl. Physiol. (1985) 2002, 92, 1655-1660. [CrossRef] [PubMed]

80. Deplancke, B.; Finster, K.; Graham, W.V.; Collier, C.T.; Thurmond, J.E.; Gaskins, H.R. Gastrointestinal and microbial responses to sulfate-supplemented drinking water in mice. Exp. Biol. Med. (Maywood) 2003, 228, 424-433. [PubMed]

81. Jørgensen, J.; Mortensen, P.B. Hydrogen sulfide and colonic epithelial metabolism: Implications for ulcerative colitis. Dig. Dis. Sci. 2001, 46, 1722-1732. [CrossRef] [PubMed]

82. Furne, J.; Springfield, J.; Koenig, T.; DeMaster, E.; Levitt, M.D. Oxidation of hydrogen sulfide and methanethiol to thiosulfate by rat tissues: A specialized function of the colonic mucosa. Biochem. Pharmacol. 2001, 62, 255-259. [CrossRef]

83. Levitt, M.D.; Furne, J.; Springfield, J.; Suarez, F.; DeMaster, E. Detoxification of hydrogen sulfide and methanethiol in the cecal mucosa. J. Clin. Investig. 1999, 104, 1107-1114. [CrossRef] [PubMed]

84. Flannigan, K.L.; McCoy, K.D.; Wallace, J.L. Eukaryotic and prokaryotic contributions to colonic hydrogen sulfide synthesis. Am. J. Physiol. Gastrointest. Liver Physiol. 2011, 301, G188-G193. [CrossRef] [PubMed]

85. Roediger, W.E.W.; Duncan, A.; Kapaniris, O.; Millard, S. Sulphide impairment of substrate oxidation in rat colonocytes: A biochemical basis for ulcerative colitis? Clin. Sci. (Lond.) 1993, 85, 623-627. [CrossRef] [PubMed]

86. Motta, J.P.; Flannigan, K.L.; Agbor, T.A.; Beatty, J.K.; Blackler, R.W.; Workentine, M.L.; Da Silva, G.J.; Wang, R.; Buret, A.G.; Wallace, J.L. Hydrogen sulfide protects from colitis and restores intestinal microbiota biofilm and mucus production. Inflamm. Bowel. Dis. 2015, 21, 1006-1017. [CrossRef] [PubMed]

87. Goubern, M.; Andriamihaja, M.; Nübel, T.; Blachier, F.; Bouillaud, F. Sulfide, the first inorganic substrate for human cells. FASEB J. 2007, 21, 1699-1706. [CrossRef] [PubMed]

88. Blackler, R.W.; Motta, J.P.; Manko, A.; Workentine, M.; Bercik, P.; Surette, M.G.; Wallace, J.L. Hydrogen sulphide protects against NSAID-enteropathy through modulation of bile and the microbiota. Br. J. Pharmacol. 2015, 172, 992-1004. [CrossRef] [PubMed]

89. Nagpure, B.V.; Bian, J.S. Interaction of Hydrogen Sulfide with Nitric Oxide in the Cardiovascular System. Oxid. Med. Cell. Longev. 2016, 2016, 6904327. [CrossRef] [PubMed]

90. Meng, G.; Ma, Y.; Xie, L.; Ferro, A.; Ji, Y. Emerging role of hydrogen sulfide in hypertension and related cardiovascular diseases. Br. J. Pharmacol. 2015, 172, 5501-5511. [CrossRef] [PubMed]

91. Yu, X.H.; Cui, L.B.; Wu, K.; Zheng, X.L.; Cayabyab, F.S.; Chen, Z.W.; Tang, C.K. Hydrogen sulfide as a potent cardiovascular protective agent. Clin. Chim. Acta. 2014, 437, 78-87. [CrossRef] [PubMed] 
92. Martelli, A.; Testai, L.; Marino, A.; Breschi, M.C.; Da Settimo, F.; Calderone, V. Hydrogen sulphide: Biopharmacological roles in the cardiovascular system and pharmaceutical perspectives. Curr. Med. Chem. 2012, 19, 3325-3336. [CrossRef] [PubMed]

93. Ufnal, M.; Sikora, M. The role of brain gaseous transmitters in the regulation of the circulatory system. Curr. Pharm. Biotechnol. 2011, 12, 1322-1333. [CrossRef] [PubMed]

94. Sonobe, T.; Haouzi, P. Hydrogen sulfide concentrations in the heart following acute administration: Methodological and physiological conciderations. Am. J. Physiol. Heart Circ. Physiol. 2016. [CrossRef] [PubMed]

95. Sikora, M.; Drapala, A.; Ufnal, M. Exogenous hydrogen sulfide causes different hemodynamic effects in normotensive and hypertensive rats via neurogenic mechanisms. Pharmacol. Rep. 2014, 66, 751-758. [CrossRef] [PubMed]

96. Szabo, C. Roles of hydrogen sulfide in the pathogenesis of diabetes mellitus and its complications. Antioxid. Redox Signal. 2012, 17, 68-80. [CrossRef] [PubMed]

97. Wallace, J.L.; Wang, R. Hydrogen sulfide-based therapeutics: Exploiting a unique but ubiquitous gasotransmitter. Nat. Rev. Drug Discov. 2015, 14, 329-345. [CrossRef] [PubMed]

98. Cortese-Krott, M.M.; Kuhnle, G.G.C.; Dyson, A.; Fernandez, B.O.; Grman, M.; DuMond, J.F.; Barrow, M.P.; McLeod, G.; Nakagawa, H.; Ondrias, K.; et al. Key bioactive reaction products of the $\mathrm{NO} / \mathrm{H}_{2} \mathrm{~S}$ interaction are S/N-hybrid species, polysulfides, and nitroxyl. Proc. Natl. Acad. Sci. USA 2015, 112, E4651-E4660. [CrossRef] [PubMed]

99. Berenyiova, A.; Grman, M.; Mijuskovic, A.; Stasko, A.; Misak, A.; Nagy, P.; Ondriasova, E.; Cacanyiova, S.; Brezova, V.; Feelisch, M. The reaction products of sulfide and S-nitrosoglutathione are potent vasorelaxants. Nitric Oxide 2015, 46, 123-130. [CrossRef] [PubMed]

100. Doel, J.J.; Benjamin, N.; Hector, M.P.; Rogers, M.; Allaker, R.P. Evaluation of bacterial nitrate reduction in the human oral cavity. Eur. J. Oral Sci. 2005, 113, 14-19. [CrossRef] [PubMed]

101. Weitzberg, E.; Lundberg, J.O.N. Nonenzymatic nitric oxide production in humans. Nitric Oxide 1998, 2, 1-7. [CrossRef] [PubMed]

102. Lundberg, J.O.; Weitzberg, E.; Cole, J.A.; Benjamin, N. Nitrate, bacteria and human health. Nat. Rev. Microbiol. 2004, 2, 593-602. [CrossRef] [PubMed]

103. Sobko, T.; Reinders, C.; Norin, E.; Midtvedt, T.; Gustafsson, L.E.; Lundberg, J.O. Gastrointestinal nitric oxide generation in germ-free and conventional rats. Am. J. Physiol. Gastrointest. Liver Physiol. 2004, 287, G993-G997. [CrossRef] [PubMed]

104. Sobko, T.; Reinders, C.I.; Jansson, E.Å.; Norin, E.; Midtvedt, T.; Lundberg, J.O. Gastrointestinal bacteria generate nitric oxide from nitrate and nitrite. Nitric. Oxide 2005, 13, 272-278. [CrossRef] [PubMed]

105. Silaghi-Dumitrescu, R.; Kim, Y.N.; Viswanathan, R.; Kurtz, D.M., Jr. A flavo-diiron protein from Desulfovibrio vulgaris with oxidase and nitric oxide reductase activities. Evidence for an in vivo nitric oxide scavenging function. Biochemistry 2005, 44, 3572-3579. [CrossRef] [PubMed]

106. Stanek, A.; Gadowska-Cicha, A.; Gawron, K.; Wielkoszyński, T.; Adamek, B.; Cieślar, G.; Wiczkowski, A.; Sieron, A. Role of nitric oxide in physiology and pathology of the gastrointestinal tract. Mini Rev. Med. Chem. 2008, 8, 1549-1560. [CrossRef] [PubMed]

107. Hirst, D.G.; Robson, T. Nitric oxide physiology and pathology. Methods Mol. Biol. 2011, 704, 1-13. [PubMed]

108. Lundberg, J.O.; Weitzberg, E. Biology of nitrogen oxides in the gastrointestinal tract. Gut 2013, 62, 616-629. [CrossRef] [PubMed]

109. Farrugia, G.; Szurszewski, J.H. Carbon monoxide, hydrogen sulfide, and nitric oxide as signaling molecules in the gastrointestinal tract. Gastroenterology 2014, 147, 303-313. [CrossRef] [PubMed]

110. Bohlen, H.G. Nitric oxide and the cardiovascular system. Compr. Physiol. 2015, 5, 803-828.

111. Lei, J.; Vodovotz, Y.; Tzeng, E.; Billiar, T.R. Nitric oxide, a protective molecule in the cardiovascular system. Nitric Oxide 2013, 35, 175-185. [CrossRef] [PubMed]

112. Dias, R.G.; Negrão, C.E.; Krieger, M.H. Nitric oxide and the cardiovascular system: Cell activation, vascular reactivity and genetic variant. Arq. Bras. Cardiol. 2011, 96, 68-75. [PubMed]

113. Çengel, A.; Şahinarslan, A. Nitric oxide and cardiovascular system. Anadolu Kardiyol. Derg. 2006, 6, 364-368. [PubMed]

114. Llorens, S.; Jordán, J.; Nava, E. The nitric oxide pathway in the cardiovascular system. J. Physiol. Biochem. 2002, 58, 179-188. [CrossRef] [PubMed] 
115. Briskey, D.; Tucker, P.S.; Johnson, D.W.; Coombes, J.S. Microbiota and the nitrogen cycle: Implications in the development and progression of CVD and CKD. Nitric Oxide 2016, 57, 64-70. [CrossRef] [PubMed]

116. Tiso, M.; Schechter, A.N. Nitrate reduction to nitrite, nitric oxide and ammonia by gut bacteria under physiological conditions. PLoS ONE 2015, 10, e0119712.

117. Regan, J.M.; Harrington, G.W.; Noguera, D.R. Ammonia- and nitrite-oxidizing bacterial communities in a pilot-scale chloraminated drinking water distribution system. Appl. Environ. Microbiol. 2002, 68, 73-81. [CrossRef] [PubMed]

118. Heiss, C.; Lauer, T.; Dejam, A.; Kleinbongard, P.; Hamada, S.; Rassaf, T.; Matern, S.; Feelisch, M.; Kelm, M. Plasma nitroso compounds are decreased in patients with endothelial dysfunction. J. Am. Coll. Cardiol. 2006, 47, 573-579. [CrossRef] [PubMed]

119. Frea, S.; Bovolo, V.; Pidello, S.; Canavosio, F.G.; Botta, M.; Bergerone, S.; Gaita, F. Clinical and prognostic role of ammonia in advanced decompensated heart failure the cardio-abdominal syndrome? Int. J. Cardiol. 2015, 195, 53-60. [CrossRef] [PubMed]

120. Medeiros, W.M.; Carvalho, A.C.; Peres, P.; De Luca, F.A.; Gun, C. The dysfunction of ammonia in heart failure increases with an increase in the intensity of resistance exercise, even with the use of appropriate drug therapy. Eur. J. Prev. Cardiol. 2014, 21, 135-144. [CrossRef] [PubMed]

121. Monteiro, M.; Séneca, J.; Magalhães, C. The history of aerobic ammonia oxidizers: From the first discoveries to today. J. Microbiol. 2014, 52, 537-547. [CrossRef] [PubMed]

122. Bełtowski, J.; Jamroz, A.; Borkowska, E. Heme oxygenase and carbon monoxide in the physiology and pathology of the cardiovascular system. Postepy. Hig. Med. Dosw. 2004, 58, 83-99.

123. Durante, W.; Johnson, F.K.; Johnson, R.A. Role of carbon monoxide in cardiovascular function. J. Cell. Mol. Med. 2006, 10, 672-686. [CrossRef] [PubMed]

124. Maharshak, N.; Ryu, H.S.; Fan, T.J.; Onyiah, J.C.; Schulz, S.; Otterbein, S.L.; Wong, R.; Hansen, J.J.; Otterbein, L.E.; Carroll, I.M.; Plevy, S.E. Escherichia coli heme oxygenase modulates host innate immune responses. Microbiol. Immunol. 2015, 59, 452-465. [CrossRef] [PubMed]

125. Onyiah, J.C.; Sheikh, S.Z.; Maharshak, N.; Steinbach, E.C.; Russo, S.M.; Kobayashi, T.; Mackey, L.C.; Hansen, J.J.; Moeser, A.J.; Rawls, J.F.; Borst, L.B.; Otterbein, L.E.; Plevy, S.E. Carbon monoxide and heme oxygenase-1 prevent intestinal inflammation in mice by promoting bacterial clearance. Gastroenterology 2013, 144, 789-798. [CrossRef] [PubMed]

126. Garcia, J.L.; Patel, B.K.C.; Ollivier, B. Taxonomic, phylogenetic, and ecological diversity of methanogenic Archaea. Anaerobe 2000, 6, 205-226. [CrossRef] [PubMed]

127. Liu, Y.; Whitman, W.B. Metabolic, phylogenetic, and ecological diversity of the methanogenic archaea. Ann. N. Y. Acad. Sci. 2008, 1125, 171-189. [CrossRef] [PubMed]

128. Ferry, J.G. Enzymology of one-carbon metabolism in methanogenic pathways. FEMS Microbiol. Rev. 1999, 23, 13-38. [CrossRef] [PubMed]

129. Whiticar, M.J.; Faber, E.; Schoell, M. Biogenic methane formation in marine and freshwater environments: $\mathrm{CO}_{2}$ reduction vs. acetate fermentation-Isotope evidence. Geochim. Cosmochim. Acta 1986, 50, 693-709. [CrossRef]

130. McKay, L.F.; Holbrook, W.P.; Eastwood, M.A. Methane and hydrogen production by human intestinal anaerobic bacteria. Acta Pathol. Microbiol. Immunol. Scand. B 1982, 90, 257-260. [CrossRef] [PubMed]

131. Christl, S.U.; Gibson, G.R.; Cummings, J.H. Role of dietary sulphate in the regulation of methanogenesis in the human large intestine. Gut 1992, 33, 1234-1238. [CrossRef] [PubMed]

132. Roccarina, D.; Lauritano, E.C.; Gabrielli, M.; Franceschi, F.; Ojetti, V.; Gasbarrini, A. The role of methane in intestinal diseases. Am. J. Gastroenterol. 2010, 105, 1250-1256. [CrossRef] [PubMed]

133. Boros, M.; Tuboly, E.; Mészáros, A.; Amann, A. The role of methane in mammalian physiology-Is it a gasotransmitter? J. Breath Res. 2015, 9, 014001. [CrossRef] [PubMed]

134. Levitt, M.D.; Furne, J.K.; Kuskowski, M.; Ruddy, J. Stability of human methanogenic flora over 35 years and a review of insights obtained from breath methane measurements. Clin. Gastroenterol. Hepatol. 2006, 4, 123-129. [CrossRef] [PubMed]

135. McKay, L.F.; Eastwood, M.A.; Brydon, W.G. Methane excretion in man-A study of breath, flatus, and faeces. Gut 1985, 26, 69-74. [CrossRef] [PubMed] 
136. Furnari, M.; Savarino, E.; Bruzzone, L.; Moscatelli, A.; Gemignani, L.; Gianini, E.G.; Zentilin, P.; Dulbecco, P.; Savarino, V. Reassessment of the role of methane production between irritable bowel syndrome and functional constipation. J. Gastrointest. Liver Dis. 2012, 21, 157-163.

137. Bratten, J.R.; Spanier, J.; Jones, M.P. Lactulose breath testing does not discriminate patients with irritable bowel syndrome from healthy controls. Am. J. Gastroenterol. 2008, 103, 958-963. [CrossRef] [PubMed]

138. Lee, K.M.; Paik, C.N.; Chung, W.C.; Yang, J.M.; Choi, M.G. Breath methane positivity is more common and higher in patients with objectively proven delayed transit constipation. Eur. J. Gastroenterol. Hepatol. 2013, 25, 726-732. [CrossRef] [PubMed]

139. Pimentel, M.; Lin, H.C.; Enayati, P.; Van Den Burg, B.; Lee, H.R.; Chen, J.H.; Park, S.; Kong, Y.; Conklin, J. Methane, a gas produced by enteric bacteria, slows intestinal transit and augments small intestinal contractile activity. Am. J. Physiol. Gastrointest. Liver Physiol. 2006, 290, G1089-G1095. [CrossRef] [PubMed]

140. Jahng, J.; Jung, I.S.; Choi, E.J.; Conklin, J.L.; Park, H. The effects of methane and hydrogen gases produced by enteric bacteria on ileal motility and colonic transit time. Neurogastroenterol. Motil. 2012, 24, 185-192. [CrossRef] [PubMed]

141. Pimentel, M.; Kong, Y.; Park, S. IBS Subjects with Methane on Lactulose Breath Test Have Lower Postprandial Serotonin Levels Than Subjects with Hydrogen. Dig. Dis. Sci. 2004, 49, 84-87. [CrossRef] [PubMed]

142. Liu, Y.; Luo, H.S.; Liang, C.B.; Tan, W.; Xia, H.; Xu, W.J. Effects of methane on proximal colon motility of rats and ion channel mechanisms. Zhonghua Yi Xue Za Zhi 2013, 93, 459-463. [PubMed]

143. Mathur, R.; Kim, G.; Morales, W.; Sung, J.; Rooks, E.; Pokkunuri, V.; Weitsman, S.; Barlow, G.M.; Chang, C.; Pimentel, M. Intestinal Methanobrevibacter smithii but not total bacteria is related to diet-induced weight gain in rats. Obesity 2013, 21, 748-754. [CrossRef] [PubMed]

144. Mathur, R.; Amichai, M.; Chua, K.S.; Mirocha, J.; Barlow, G.M.; Pimentel, M. Methane and hydrogen positivity on breath test is associated with greater body mass index and body fat. J. Clin. Endocrinol. Metab. 2013, 98, E698-E702. [CrossRef] [PubMed]

145. Romano, K.A.; Vivas, E.I.; Amador-Noguez, D.; Rey, F.E. Intestinal microbiota composition modulates choline bioavailability from diet and accumulation of the proatherogenic metabolite trimethylamine- $N$-oxide. mBio 2015, 6, e02481. [CrossRef] [PubMed]

146. Koeth, R.A.; Wang, Z.; Levison, B.S.; Buffa, J.A.; Org, E.; Sheehy, B.T.; Britt, E.B.; Fu, X.; Wu, Y.; Li, L.; et al. Intestinal microbiota metabolism of L-carnitine, a nutrient in red meat, promotes atherosclerosis. Nat. Med. 2013, 19, 576-585. [CrossRef] [PubMed]

147. Ufnal, M.; Jazwiec, R.; Dadlez, M.; Drapala, A.; Sikora, M.; Skrzypecki, J. Trimethylamine-N-oxide: A carnitine-derived metabolite that prolongs the hypertensive effect of angiotensin II in rats. Can. J. Cardiol. 2014, 30, 1700-1705. [CrossRef] [PubMed]

148. Fukami, K.; Yamagishi, S.I.; Sakai, K.; Kaida, Y.; Yokoro, M.; Ueda, S.; Wada, Y.; Takeuchi, M.; Shimizu, M.; Yamazaki, H.; Okuda, S. Oral L-carnitine supplementation increases trimethylamine- $N$-oxide but reduces markers of vascular injury in hemodialysis patients. J. Cardiovasc. Pharmacol. 2015, 65, 289-295. [CrossRef] [PubMed]

149. Lee, J.H.; Lee, J. Indole as an intercellular signal in microbial communities. FEMS Microbiol. Rev. 2010, 34, 426-444. [CrossRef] [PubMed]

150. DeMoss, R.D.; Moser, K. Tryptophanase in diverse bacterial species. J. Bacteriol. 1969, 98, 167-171. [PubMed]

151. Smith, E.A.; Macfarlane, G.T. Formation of phenolic and indolic compounds by anaerobic bacteria in the human large intestine. Microbial. Ecol. 1997, 33, 180-188. [CrossRef]

152. Darkoh, C.; Chappell, C.; Gonzales, C.; Okhuysen, P. A rapid and specific method for the detection of indole in complex biological samples. Appl. Environ. Microbiol. 2015, 81, 8093-8097. [CrossRef] [PubMed]

153. Kim, J.; Park, W. Indole: A signaling molecule or a mere metabolic byproduct that alters bacterial physiology at a high concentration? J. Microbiol. 2015, 53, 421-428. [CrossRef] [PubMed]

154. Atoh, K.; Itoh, H.; Haneda, M. Serum indoxyl sulfate levels in patients with diabetic nephropathy: Relation to renal function. Diabetes Res. Clin. Pract. 2009, 83, 220-226. [CrossRef] [PubMed]

155. Yoshikawa, D.; Ishii, H.; Suzuki, S.; Takeshita, K.; Kumagai, S.; Hayashi, M.; Niwa, T.; Izawa, H.; Murohara, T. Plasma Indoxyl sulfate and estimated Glomerular filtration rate-Association with long-term clinical outcome in patients with coronary artery disease. Circ. J. 2014, 78, 2477-2482. [CrossRef] [PubMed] 
156. Barreto, F.C.; Barreto, D.V.; Liabeuf, S.; Meert, N.; Glorieux, G.; Temmar, M.; Choukroun, G.; Vanholder, R.; Massy, Z.A. Serum indoxyl sulfate is associated with vascular disease and mortality in chronic kidney disease patients. Clin. J. Am. Soc. Nephrol. 2009, 4, 1551-1558. [CrossRef] [PubMed]

157. Wu, I.W.; Hsu, K.H.; Lee, C.C.; Sun, C.Y.; Hsu, H.J.; Tsai, C.J.; Tzen, C.Y.; Wang, Y.C.; Lin, C.Y.; Wu, M.S. P-cresyl sulphate and indoxyl sulphate predict progression of chronic kidney disease. Nephrol. Dial. Transplant. 2011, 26, 938-947. [CrossRef] [PubMed]

158. Lekawanvijit, S.; Kompa, A.R.; Manabe, M.; Wang, B.H.; Langham, R.G.; Nishijima, F.; Kelly, D.J.; Krum, H. Chronic kidney disease-induced cardiac fibrosis is ameliorated by reducing circulating levels of a non-dialysable uremic toxin, indoxyl sulfate. PLOS ONE 2012, 7, e41281. [CrossRef] [PubMed]

159. Miyazaki, T.; Aoyama, I.; Ise, M.; Seo, H.; Niwa, T. An oral sorbent reduces overload of indoxyl sulphate and gene expression of TGF- $\beta 1$ in uraemic rat kidneys. Nephrol. Dial. Transplant. 2000, 15, 1773-1781. [CrossRef] [PubMed]

160. Lekawanvijit, S.; Adrahtas, A.; Kelly, D.J.; Kompa, A.R.; Wang, B.H.; Krum, H. Does indoxyl sulfate, a uraemic toxin, have direct effects on cardiac fibroblasts and myocytes? Eur. Heart J. 2010, 31, 1771-1779. [CrossRef] [PubMed]

161. Bansal, T.; Alaniz, R.C.; Wood, T.K.; Jayaraman, A. The bacterial signal indole increases epithelial-cell tight-junction resistance and attenuates indicators of inflammation. Proc. Natl. Acad. Sci. USA 2010, 107, 228-233. [CrossRef] [PubMed]

162. Zelante, T.; Iannitti, R.; Cunha, C.; DeLuca, A.; Giovannini, G.; Pieraccini, G.; Zecchi, R.; D’Angelo, C.; Massi-Benedetti, C.; Fallarino, F.; Carvalho, A.; Puccetti, P.; Romani, L. Tryptophan catabolites from microbiota engage aryl hydrocarbon receptor and balance mucosal reactivity via interleukin-22. Immunity 2013, 39, 372-385. [CrossRef] [PubMed]

163. Richardson, A.J.; McKain, N.; Wallace, R.J. Ammonia production by human faecal bacteria, and the enumeration, isolation and characterization of bacteria capable of growth on peptides and amino acids. BMC Microbiol. 2013, 13. [CrossRef] [PubMed]

164. Zhang, Q.; Meng, Z. The inotropic effects of ammonia on isolated perfused rat hearts and the mechanisms involved. J. Exp. Biol. 2011, 214, 4048-4054. [CrossRef] [PubMed]

165. Perry, B.G.; Pritchard, H.J.; Barnes, M.J. Cerebrovascular, cardiovascular and strength responses to acute ammonia inhalation. Eur. J. Appl. Physiol. 2016, 116, 583-592. [CrossRef] [PubMed] 